\title{
ワッシャーを用いたリベット締結法の提案と炎の効果*
}

\author{
木之下 広幸*1, 海 津 浩 一*2, 外 山眞 也*3 \\ 佐 藤征 覀 ${ }^{* 4}$, 徳 永 仁夫*5, 池田清 彦*1
}

\section{Proposal and Effect of Riveting Process Using the Washer}

\author{
Hiroyuki KINOSHITA*6, Koichi KAIZU, Masaya TOYAMA, \\ Masatsugu SATO, Hitoo TOKUNAGA and Kiyohiko IKEDA
}

\author{
${ }^{* 6}$ Mechanical Systems Engineering, University of Miyazaki, \\ 1-1 Gakuenkibanadai-nishi, Miyazaki-shi, Miyazaki, 889-2192 Japan
}

\begin{abstract}
In riveting, it is very important to make the plate's deformation small as well as to obtain the high joint strength. Therefore, we proposed the new riveting process using the washer in the same way as the bolt joint in order to accomplish both purposes. In this paper, first, by changing the combinations of hardness and flow stresses of the rivet material and the plate, we investigated the deformation and strength of the joints in detail and clarified the characteristics of the joints. Next, by considering these experimental results, the new method using the washer in riveting was proposed and the effectiveness of the proposed method was examined. The obtained results show that the joint strength is improved while the deformation of the joint decreases. The usefulness of the proposed method was confirmed from those results.
\end{abstract}

Key Words: Machine Element, Fixing Element, Riveting, Joint Strength, Washer, Plate's Distortion, Hardness

\section{1. 緒言}

リベット締結では，板のひずみや反りなどの変形を 小さく抑えつつ高い締結強度を得ることが重要である. しかしながら，両者は相反するものであり，これらを 両立できるリベットの締結条件を見い出すことは非常 に重要な課題である.リベット締結において板のひず みや反りが生じる原因は, リベット頭部と板との間に 生じる圧力とリベット軸の太りによって生じる穴内の 圧力によって, 板の穴周囲が塑性変形することによる. また一方で, 締結強度は, それらのリベットと板との 間の圧力によって変わり, 板の穴周囲の塑性変形状態 と密接な関係があることが著者らの研究 ${ }^{(1),(2)}$ から明 らかにされている.一般に, リベット材と板材には同 種類の材料が使用されるが，板の穴周囲の塑性変形状 態は，板材とリベット材の硬度と強度によって変化す る. そのため, 適切なリベットの締結条件を見い出す

\footnotetext{
* 原稿受付 2008 年 4 月 14 日.

*1 正員, 宮崎大学工学部 (画 889-2192 宮崎市学園木花台西 11).

*2 正員, 兵庫県立大学大学院工学研究科(业671-2280 姬路市 書写 2167)

*3 正員, 宮崎県工業技術センター ( $880-0303$ 宮崎市佐土原 町東上那珂 16500-2).

*4 宮崎県工業技術センター。

*5 正員, 宇部工業高等専門学校 (画 755-8555 宇部市常盤台 214-1).

E-mail : t0d165u@cc.miyazaki-u.ac.jp
}

ためには，リベット材と板材の硬度と強度の違いによ って, 継手の変形と強度がどのように変わるかを理解 しておく必要がある.

そこで本研究では, 先ず, リベット材と板材の硬度 および変形抵抗の違いに着目し，リベット材と板材の 組合せを数種変えてリベット締結を行い，継手の変形 と締結強度の特徵ならびに問題点を明らかにした. 次 に，それらの問題点を改善するために，ねじ締結と同 様にワッシャーを用いてリベット締結する方法を提案 し，その効果について実験および有限要素解析を行い 検討した. そして，提案した手法により継手の変形を 小さく抑えられるとともに高い締結強度が得られるこ とを示した.

\section{2. リベット材と板材の組合せを変えた 場合の継手の変形と強度}

$2 \cdot 1$ リベット締結の方法 表 1 は, 実験で用い たリベット材と板材の組合せを示している. また図 1 は, リベット材と板材の変形抵抗曲線（真応力一真ひ ず夕曲線）を示している，なお，変形抵抗曲線は，万 能試験機を用いて, リベット材については単軸圧縮試 験を行い, 板材については引張試験を行って求めた. 
表 1 のは，リベット材と板材の硬度および変形抵 抗が同じ程度の場合の継手の変形とその締結強度につ いて検討するために, 初期硬さ $28 \mathrm{Hv}$ のアルミニウム合 金 A1070BD 材から作製したリベットと初期硬さ $26 \mathrm{Hv}$ のアルミニウム合金 A1100P-0 材の板を組合せている. また，表 1 の(2)，板材の硬度がリベット材の硬度よ りも高く, 変形抵抗も相対的に大きい場合について検 討するために, 初期硬さ $28 \mathrm{Hv}$ の A1070BD 材から作製 したリベットと初期硬さ 40Hv の A1100P-H14 材の板を 組合せている，同様に，表 1 (3)は，表 1 (1)を基淮 にして, リベット材の硬度が板材よりも高く, 変形抵 抗も相対的に大きい場合の継手の変形と強度について 検討するために, 初期硬さ $70 \mathrm{Hv}$ のアルミニウム合金 A5052BD 材から作製したリベットと初期硬さ $26 \mathrm{Hv}$ の A1100P-0材の板を組合せている. なお, 表 1 の(1) と(3) に示寸硬さ $26 \mathrm{Hv}$ の A1100P-0 材の板は, 表 1 の(2)に示 す硬さ $40 \mathrm{Hv}$ の $\mathrm{A} 1100 \mathrm{P}-\mathrm{H} 14$ 材の板を $350^{\circ} \mathrm{C} て ゙ ~ 3$ 時間の 焼鈍を行うことで, 硬さを低下させたものである.

図 2 は, 本研究で用いたリベット締結の方法の概要 を示している. リベット直径 $d_{0}$ と板厚 $t$ の関係には, 式(1)に示寸構造用継手のリベット直径と板厚の関係 式 ${ }^{(3)}$ を用いることとし, 軸直径 $8 \mathrm{~mm}$ のリベットと厚 さ2 $\mathrm{mm}$ の板を用いて単せん断重ね継手を作製した.

$$
d_{0}=\sqrt{50 t}-2 \quad(\mathrm{~mm})
$$

なお，リベットは，予め直径 $8 \mathrm{~mm}$, 長さ $27 \mathrm{~mm}$ の棒材 を用いて据込み加工により作製した，パンチには，フ ラットタイプを用いた，予め作製したリベットは，軸 直径を $d_{0}(8 \mathrm{~mm})$ とすると, 頭部の直径を約 $1.7 d_{0}$ に成形 している. 板の寸法は, 厚さ $2 \mathrm{~mm}$, 幅 $36 \mathrm{~mm}$, 長さ $100 \mathrm{~mm}$ で，きりもみ後にリーマ通しを行って $\phi 8.5$ の穴をあ け，2枚の板を重社合わせて継手を作製した.

図 3 は, 継手の強度試験の方法を示している. 継手 の強度試験は, オートグラフ (島津製 $\mathrm{AG}-500 \mathrm{~A}$ ) を用 いて, $10 \mathrm{~mm} / \mathrm{min} の 一$ 定速度で, 締結した板の両端を引 張ることにより行った.

\section{$2 \cdot 2$ 実験結果}

\subsection{1 リベット締め荷重と軸の太りについて}

リベット締結した継手の変形とその締結強度は, リ ベット締め荷重とリベット軸の太りの状況によって大 きく変わることが知られている(1).そこで先ず，表 1 の(1)と(3)の組合せの場合のリベット締め荷重とリベッ 卜軸の太りの状況について検討した.

図 4(A)は, リベット締め荷重と $\left(D / d_{\partial}\right)$ の関係を表し ている.ここで， $\left(D / d_{0}\right)$ は, リベット頭部の直径 $D$ と リベット軸初期の直径 $d_{0}$ の比を表している. この図か
Table l Combinations of rivet and plate

\begin{tabular}{|c|c|c|}
\hline & $\begin{array}{c}\text { Rivet material } \\
\text { (Bar, Diameter: } \phi \text { 8) }\end{array}$ & $\begin{array}{c}\text { Plate material } \\
\text { (Thickness: } 2 \mathrm{~mm} \text {, Width: } \\
\text { 36mm, Rivet hole: } \phi 8.5 \text { ) }\end{array}$ \\
\hline (1) & $\begin{array}{c}\text { A1070BD } \\
\text { Initial hardness: } 28 \mathrm{Hv} \\
0.2 \% \text { proof stress: } 67 \mathrm{MPa}\end{array}$ & $\begin{array}{c}\text { A1100P-O } \\
\text { Initial hardness: } 26 \mathrm{Hv} \\
0.2 \% \text { proof stress: } 62 \mathrm{MPa}\end{array}$ \\
\hline (2) & $\begin{array}{c}\text { A1070BD } \\
\text { Initial hardness: } 28 \mathrm{Hv} \\
0.2 \% \text { proof stress: } 67 \mathrm{MPa}\end{array}$ & $\begin{array}{c}\text { A1100P-H14 } \\
\text { Initial hardness: } 40 \mathrm{Hv}\end{array}$ \\
\hline (3) & $\begin{array}{c}\text { A5052BD } \\
\text { Initial hardness: } 70 \mathrm{Hv}\end{array}$ & $\begin{array}{c}\text { A1100P-O stress: } 103 \mathrm{MPa} \\
\text { Initial hardness: } 26 \mathrm{Hv}\end{array}$ \\
$0.2 \%$ proof stress: $170 \mathrm{MPa}$ & $0.2 \%$ proof stress: $62 \mathrm{MPa}$ \\
\hline
\end{tabular}

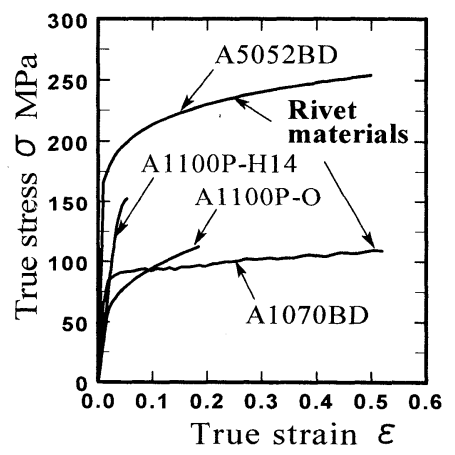

Fig.1 True stress- true strain curves for rivet materials and plate materials

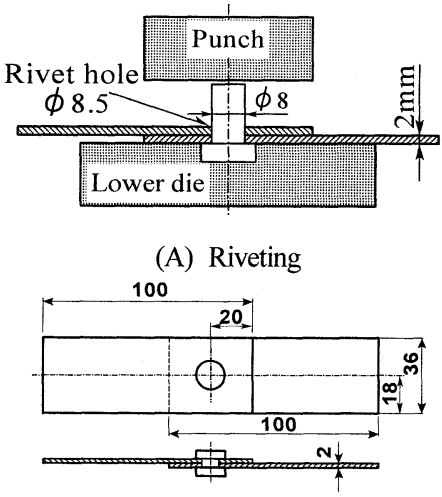

(B) Joint

Fig.2 Schematic illustrations of riveting and dimension of joint

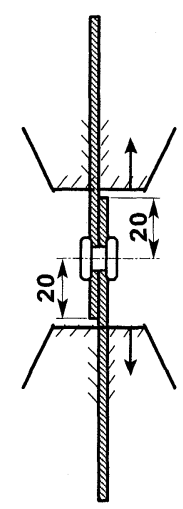

Fig.3 Tension test of joint
ら, リベット締め荷重は， $(D / d)$ の増加とともにかな り増加すること, A5052BD 材のリベットを用いた場合 は，A1070BD 材のリベットを用いた場合よりも 2 倍以 上のリベット締め荷重が必要であることがわかる. 

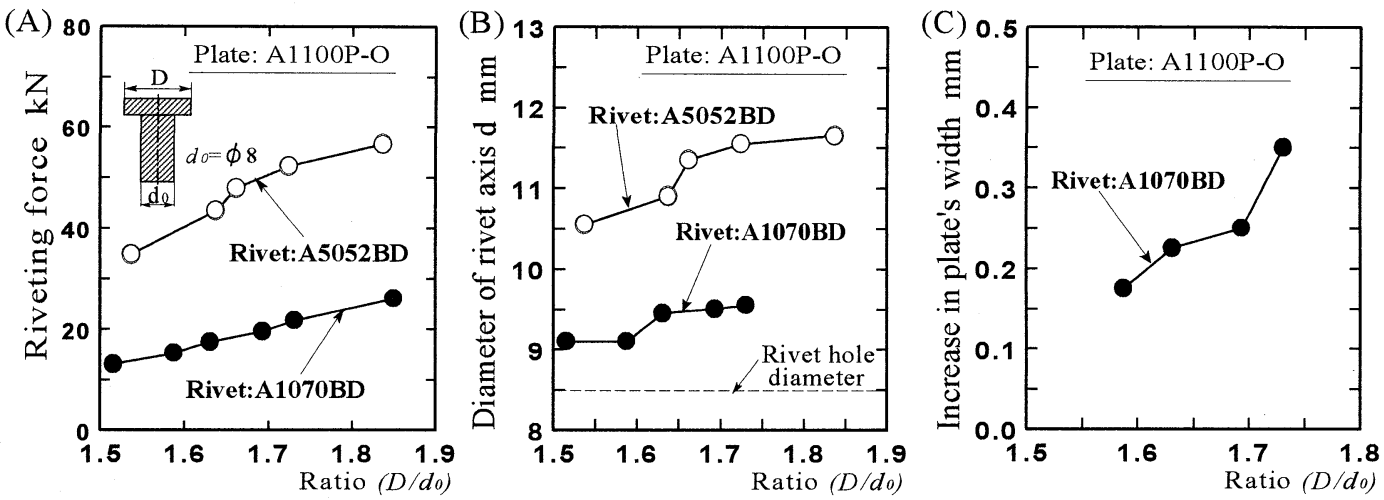

Fig.4 (A) Relationship between riveting force and $\left(D / d_{0}\right)$, (B) Relationship between diameter of rivet axis and $\left(D / d_{0}\right)$,

(C) Relationship between change of plate's width and $\left(D / d_{0}\right)$

図 4 (B) は，締結後のリベット軸の直径 $d$ と $\left(D / d_{0}\right)$ の 関係を表している，なお，リベット軸の直径 $d$ は，リ ベット締結した板を切断して測定している. この図か ら, 通常リベット頭部の直径は，1.6〜1.7 $d_{0}$ に成形さ れるが，頭部の直径を $1.6 d_{0}$ 以上に成形した場合，い ずれもリベット軸は，板の穴の直径よりも大幅に太っ ている. 特に, A5052BD 材のリベットを用いた場合は, 非常に大きな軸の太りが生じている.

図 4(C) は，締結後の継手の板幅の増加量と $\left(D / d_{0}\right)$ の 関係を表している. 板の幅は, 図 2 (B) に示すリベット 締結部の板幅を測定している. また, A5052BD 材のリ ベットを用いた継手の板幅の増加量は，板の反りが非 常に大きく，測定が困難であったので図には示してい ない，この図から，過大なりベット軸の太りは，板幅 の寸法変化をもたらすことがわかる.

\section{$2 \cdot 2 \cdot 2$ 継手の強度について}

\section{(1) A1070BD 材のリベットと A1100P-0 材の板を組合} せた場合 図 5(A) は, 継手の破壊の様相を示してい る. また, 図 5 (B) は, この場合の継手の最大引張荷重 と $\left(D / d_{0}\right)$ の関係を表している. 図中の Bearing につい ては後で述べる. 図 5(A)に示すように，継手はいずれ も引張荷重の増大とともに，板の接合面が徐々に開き つつ板の穴が拡大して破壊している．板の穴が破壊し た原因は, $\phi 8$ のリベット軸が $\phi 8.5$ の穴内に圧縮され て充満した場合, リベット軸は平均で 0.12 程度の塑性 ひずみを受け，その変形抵抗は，加工硬化により $95 \mathrm{MPa}$ 程度となり，0.2\% 耐力が $62 \mathrm{MPa}$ の板よりも大きくな るためと考えられる. 図 5(B) から, 継手の最大引張荷 重は $\left(D / d_{0}\right)$ の増加とともに増加する特徴がある. また, 継手の最大引張荷重は図 4(B) の締結後のリベット軸 の直径 $d$ と $\left(D / d_{0}\right)$ の関係から，リベット軸の太りとと もに大きくなると言うことができる.
(A)

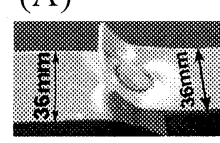

$(D / d o)=1.63$ Riveting force $=19.6 \mathrm{kN}$

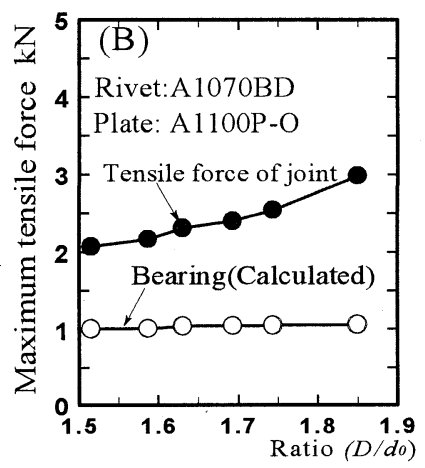

Fig.5 (A) Fracture of joint, (B) Maximum tensile force of joint in case of using $\mathrm{A} 1070 \mathrm{BD}$ rivet and $\mathrm{A} 1100 \mathrm{P}-\mathrm{O}$ plates

次に, 継手の強度について考察する，一般に，リベ ット継手の破壊は，リベットがせん断されて破壊する 場合と板の穴周囲がリベット軸によって圧縮破壊され る場合に分けられる ${ }^{(4),(5)}$. 板の穴周囲がリベット軸 によって圧縮破壊される場合の継手の強度は，式(2) で表される支圧強さ ${ }^{(4)}$ と呼ばれる $F_{p}$ で評価される.

$$
F_{p}=\sigma d t
$$

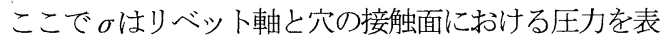
し，dはリベット軸の直径， $t$ は板厚を表す．図 5 (B) の○印で表す Bearing の線は，リベット軸と穴の接触 面における圧力 $\sigma$ に板材の $0.2 \%$ 耐力 $(62 \mathrm{MPa}$ )を用い て支圧強さ $F_{p}$ を計算した結果を示している. リベット 軸の直径 $d$ は，図 4 に示した締結後の軸直径を用いて いる. 実験により得られた継手の最大引張荷重は, 式 (2)で計算した支圧強さよりもかなり高く, 1.8 倍〜 2.8 倍となっている.この継手の最大引張荷重と式(2) で計算した支圧強さの差は, 後に $3 \cdot 4$ 項にて示寸複せ ん断継手の引張試験の結果（図 14）から，板と板の接 合面が 2 倍に増えると, 継手の最大引張荷重も 2 倍程 
度増加寸ることから，主に板と板との間の摩擦力によ って生じたものと考えられる.

(2) A1070BD 材のリベットと A1100P-H14 材の板を組 合せた場合図6は，継手の破壊の様相，ならびに この場合の継手の最大引張荷重を示している. 先ず, この場合は板材の硬度がリベット材の硬度よりも高く, 変形抵抗も相対的に大きいため, 締結後のリベット軸 の直径は，板の穴の直径とほぼ同じであった。また， 板の反りおよび板幅の寸法変化もほとんど生じていな い. 次に，図6(A)に示すように，継手はいずれもリ心゙ ット軸がせん断されることにより破壊する。この時, 継手の最大引張荷重は, 図6(B)に示すように, $\left(D / d_{0}\right)$ の大きさに依らずほぼ一定である。このようにリベッ 卜軸がせん断破壊する場合は，継手の強度評価には一 般に式(3)が用いられる.

$$
F_{s}=\left(\frac{\pi}{4} d^{2}\right) \tau_{f}
$$

ここで， $F_{S}, \tau_{f}, d$ はそれぞれ，リベット軸のせん断 強さ, リベット軸のせん断破壊応力, リベット軸の直 径を表している. 図 6(B) 中の一点鎖線で表す線は, 式 （3）で計算したリベットのせん断強さFS を表してい る. なお，リベット軸のせん断破壊応力 $\tau_{f}$ は，ミー ゼスの降伏条件を用いて, 締結後のリベット軸の変形 抵抗值を $95 \mathrm{MPa}$ とし, この值を $\sqrt{3}$ で除して求めた. 先 ず, 式(3)で計算したりベット軸のせん断強さが, 継手 の最大引張荷重に近い值となることから，継手の強度 がリベット軸のせん断強さによってほぼ決まることが 確認できる．また，リベット軸のせん断強さが一定で あることから，継手の最大引張荷重が $\left(D / d_{0}\right)$ の大き さに依らずほぼ一定であると考えられる.さらに, こ の組合せでは, 継手の最大引張荷重と式(3)で計算した リベット軸のせん断強さの差が小さいことから，引張 荷重は主にリベット軸に作用し，板と板との間の摩擦 力が引張荷重に及ぼす影響沙小さい考えられる.

(3) A5052BD 材のリベットと A1100P-0 材の板を組合 せた場合＼cjkstart先ず，この組合せの場合は，A1070BD 材 のリベットを用いた場合と同様に，いずれも板の穴周 囲が拡大して破壊しているが，紙面の都合から省略し た. 図7(A)は，A1070BD 材のリベットを用いた場合と A5052BD 材のリベットを用いた場合の継手の反りの状 況を示している. この図に示すように, A5052BD 材の リベットは, A1070BD 材のリベットよりもリベット締 め荷重が大きいため, 板の反りが非常に大きくなるこ とがわかる.この結果から, 板材よりも硬度が高く, 変形抵抗も相対的に大きいリベット材を用いると，リ ベット材と板材の硬度および変形抵抗が同じ程度の場

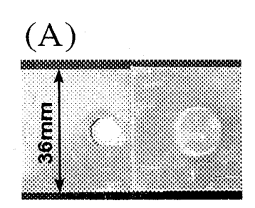

$\left(D / d_{0}\right)=1.68$ Riveting force $=19.6 \mathrm{kN}$

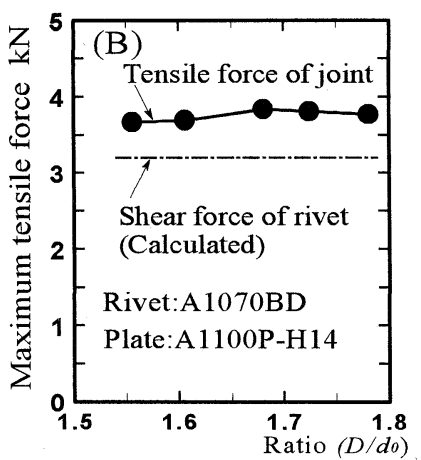

Fig.6 (A) Fracture of joint, (B) Maximum tensile force of joint in case of using A1070BD rivet and A1100P-H14 plates

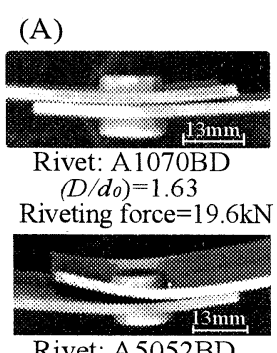

Rivet: A5052BD $(D / d o)=1.66$

Riveting force $=53.9 \mathrm{kN}$

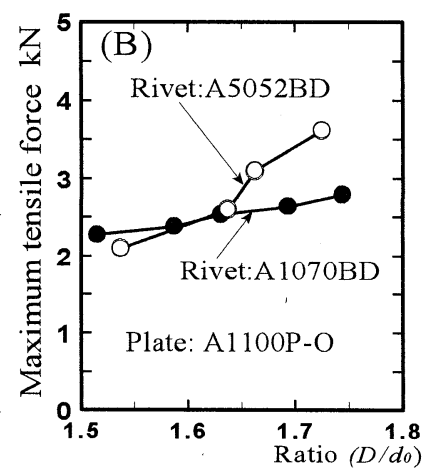

Fig.7 (A) Aspects of joints, (B) Maximum tensile force of joint in case of using $\mathrm{A} 5052 \mathrm{BD}$ rivet and $\mathrm{A} 1100 \mathrm{P}-\mathrm{O}$ plates

合よりも継手の変形は大きくなると考えられる.

図 7 (B) は，A5052BD 材のリベットを用いた場合の継 手の最大引張荷重を表している. 継手の最大引張荷重 は, $\left(D / d_{0}\right)=1.65$ 程度以上において $\mathrm{A} 1070 \mathrm{BD}$ 材のリベ ットを用いた場合よりも高い. しかし, 眓 4 に示した ように, 過大なリベット軸の太りが生じ, 継手の変形 が非常に大きくなる不具合が生じている.

以上の実験結果から, (1)リベット材と板材の硬度お よび変形抵抗が同じ程度の場合，およびリベット材の 硬度が板材よりも高く, 変形抵抗も相対的に大きい場 合において, リベット締め荷重の増加とともに過大な 軸の太りが生じや寸く, 継手の変形が大きくなりやす いこと, (2)継手の変形を小さくするためには, リベッ 卜締め荷重を小さくする必要があるが，この場合の継 手の強度は, リベット締め荷重の増加とともに増加す るので, 高い締結強度は得られないことがわかった.

\section{3. ワッシャーを用いたリベット締結}

$3 \cdot 1$ ワッシャーを用いる目的以上のことから， リベット材と板材の硬度および変形抵抗が同じ程度の 
場合，およびリベット材の硬度が板材よりも高く，変 形抵抗も相対的に大きい場合において，ワッシャーを 用いることにより，(1)過大なリベット軸の太りを抑え， 板の寸法変化を小さくすること, (2)板の穴周囲の過大 な塑性変形を抑えることにより，板の反りを小さくす ること，(3)板の穴周囲の破壊を抑制し締結強度の向上 を図ることを目指した。

\section{$3 \cdot 2$ ワッシャーを用いたリベット締結の方法}

図 8 は, ワッシャーを用いたリベット締結の方法の 概要を示している，ワッシャーには，呼び径 $8 \mathrm{~mm}$ の黄 銅製のみがき丸（面取り形）を用いた。ワッシャーの 硬さは $106 \mathrm{Hv}$ で，寸法は，厚さ $1.6 \mathrm{~mm}$ ，外径 $17 \mathrm{~mm}$ ，穴 径 $8.4 \mathrm{~mm}$ である. リベット締結は，ワッシャーにリベ ット軸を挿入することにより行い，ワッシャーをリベ ット頭部の一方のみに用いる場合と, リベット頭部の 両方に用いる場合の 2 通り行った。 なお，ワッシャー をリベット頭部の一方のみに用いる場合は，重ね合わ せた板の上側に用いた．また，ワッシャーをリベット 頭部の両方に用いる場合は，リベット頭部の体積が非 常に小さくなるので，頭部の体積を同じにするために 軸長を $2 \mathrm{~mm}$ 増したリベットを用いた。

\section{3 継手の変形と締結強度の検討}

(1) A1070BD 材のリベットと A1100P-0 材の板の組合 せでワッシャーを用いた場合＼cjkstart図 9 は，ワッシャー を用いた場合と用いない場合の継手の反りの状況とリ ベット軸の断面写真を示している。この図から，リベ ット頭部の一方のみにワッシャーを用いた場合では, 板の反りが小さくなり, リベット頭部の両方にワッシ ヤーを用いた場合では，板の反りはほとんど生じてい ない，また，リベット軸の断面写真から，リベット頭 部の両方にワッシャーを用いた場合では，リベット軸 の直径は, 板 (ワッシャー) の穴の直径とほぼ同じで, その太さが均一である. また，リベッ卜頭部の一方の みにワッシャーを用いた場合は，軸の中央部が多少樽 型に変形しているが，その太りはワッシャーを用いな い場合よりも小さい，以上のことから，ワッシャーを 用いてリベット締結することにより，過大なリベット 軸の太りを抑えるとともに，板の寸法変化と反りを小 さくすることができることがわかった.

図 10 は, この場合の継手の破壊の様相, ならびに継 手の最大引張荷重を示している. 先ず, 図 10 (A)に示 すようにリベット頭部の一方のみにワッシャーを用い て板を締結した場合では，全ての場合でワッシャーの ないもう一方の板の穴周囲が破壊し，リベット頭部の 両方にワッシャーを用いた場合では，リベット軸がせ ん断破壊している. 次に, ワッシャーを用いた場合の

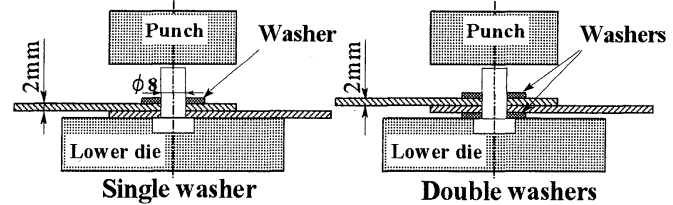

Fig.8 Riveting process using the washer

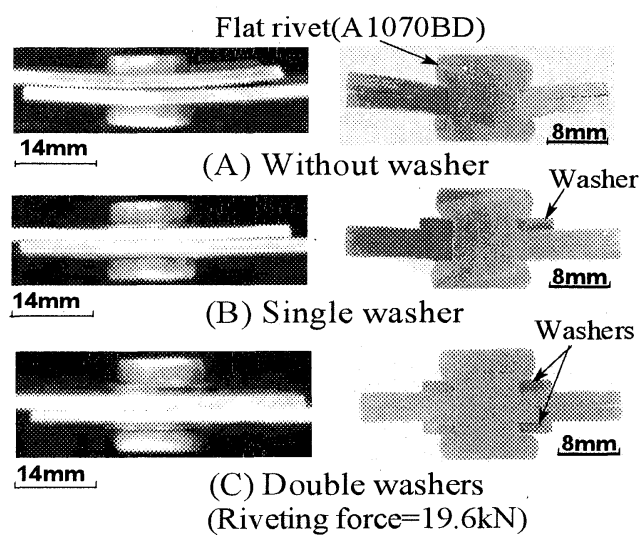

Fig.9 Aspects of joints using the washer

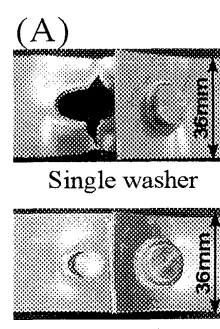

Double washers

(Riveting force $=22.05 \mathrm{kN}$ )

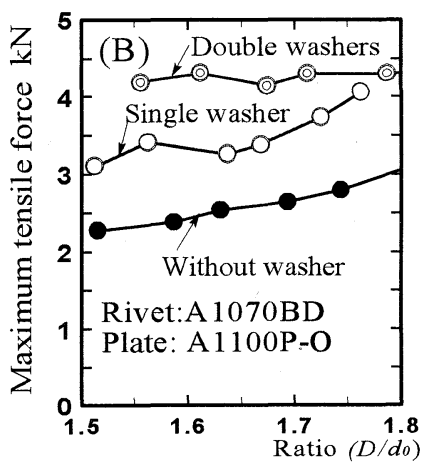

Fig.10 Fracture and maximum tensile force of joint in case of using $\mathrm{A} 1070 \mathrm{BD}$ rivet, $\mathrm{A} 1100 \mathrm{P}-\mathrm{O}$ plates and washers

継手の最大引張荷重は, 図 10(B)に示すようにワッシ ヤ一を用いない場合よりも明らかに増加し，特にリベ ット頭部の両方にワッシャーを用いた場合では，最大 引張荷重は $\left(D / d_{0}\right)$ の大きさに依らずほぼ一定で，かつ 非常に大きい，以上のことから，ワッシャーを用いて リベット締結することにより, 継手の強度も増加する ことがわかった.

(2) A1070BD 材のリベットと A1100P-H14 材の板の組 合せでワッシャーを用いた場合＼cjkstart図 11 は, A1070BD 材のリベットと A1100P-H14 材の板を用いた場合の継 手の破壊の様相，ならびに継手の最大引張荷重を示し ている，先ず，図 11(A)にはリベット頭部の両方にワ 
ッシャーを用いた場合の継手の破壊のみを示している が，リベット頭部の一方のみ，あるいは両方にワッシ ヤーを用いた場合のいずれも，継手はリベット軸がせ ん断することにより破壊している，次に，図 11(B)か ら，リベット頭部の一方のみ，あるいは両方にワッシ ヤーを用いた場合の継手の最大引張荷重は，ワッシャ 一を用いない場合とほとんど変わらない.この理由は， いずれも締結後のリベット軸の直径が，板の穴の直径 とほぼ同じであり，リベット軸のせん断強さがほぼ同 じであるためと考えられる.

(3) A5052BD 材のリベットと A1100P-0 材の板の組合 せでワッシャーを用いた場合図 12 は, A5052BD 材 のリベットと A1100P-0 材の板を用いた場合の継手の 破壊の様相，ならびに継手の最大引張荷重を示してい る.この場合の継手は, 図 12 (A)に示すように, 全て 板の穴周りが破壊している．継手の最大引張荷重は, 図 12 (B)に示寸ように，ワッシャーを用いない場合よ りも増加し, 図 10 のリベットに A1070BD 材を用いた場 合よりも相対的に大きい，この理由は，A1070BD 材の リベットを用いた場合では，両方の頭部にワッシャー を用いるとリベット軸がせん断破壊するが，A5052BD 材のリベットを用いた場合では，A1070BD 材のリベッ トよりも強度が高いためせん断破壊せず，継手はより 大きな引張荷重に耐えたと考えられる．以上のことか ら,この場合のリベット材と板材の組合せに执いても, ワッシャーを用いることにより継手の強度が増加する ことがわかった.

$3 \cdot 4$ ワッシャーの効果の理論的考察 A1070BD 材のリベットと A1100P-0 材の板を組合せた場合, およ びA5052BD材のリベットとA1100P-0材の板を組合せた 場合において，ワッシャーを用いると継手の最大引張 荷重が大幅に増加寸る理由について考察する.

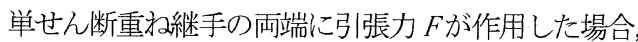
板厚を $t$ とすると, 図 13 の模式図に示すように, 板に はMFFtの曲げモーメントが作用し, 板表面近くの穴周 囲には式(4) で表される圧縮応力が作用することが知 られている(6).

$$
\sigma=\frac{F}{d t}+\frac{F t}{1 / 6 d t^{2}}
$$

式(4)において, 右辺第一項は, 引張力 Fによりリベッ 卜軸と板の穴の接触面に直接作用する圧縮応力を表し 右辺第二項は, 曲げモーメント Ftにより生じる最大圧 縮応力を表している. 継手の引張力の増大とともに板 の端部の接合面が徐々に開くのは，この曲げモーメン 卜の作用によるものと考えられる.この曲げモーメン
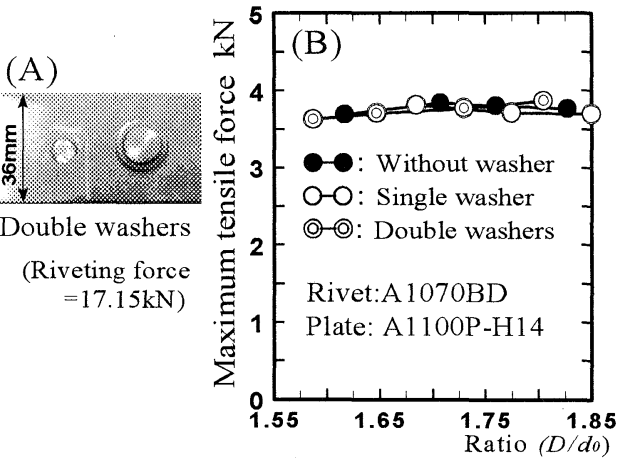

Fig.11 Fracture and maximum tensile force of joint in case of using A1070BD rivet, A1100P-H14 plates and washers
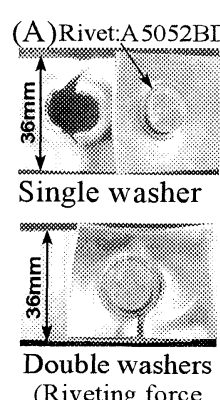

(Riveting force $=58.8 \mathrm{kN}$ )

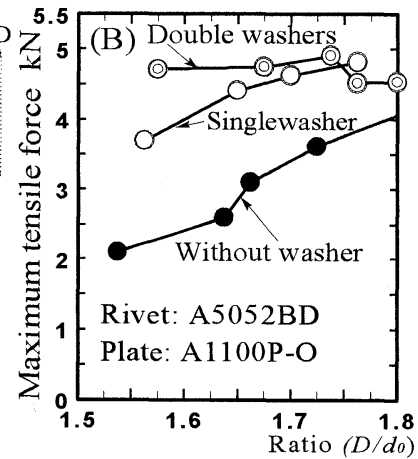

Fig.12 Fracture and maximum tensile force of joint in case of using A5052BD rivet, A1100P-O plates and washers

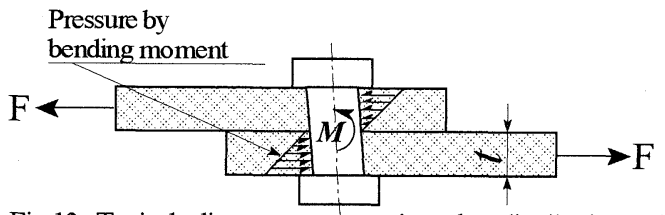

Fig.13 Typical diagram representing the distribution of bearing pressure generating by bending moment

トにより板の穴周囲に作用する圧縮応力は，板と板の 接合面上ではゼロで，リベット頭部に近づくほど大き くなる特徽がある，また，曲げモーメントによる圧縮 応力は, 継手の引張力の増加とともに増加する. これ らのことから，ワッシャーを用いない場合の単せん断 重放継手では, 式(4)に示寸圧縮応力によりリベット頭 部近くの穴周囲から塑性変形が生じ，穴が搪大寸るも のと考えられる。一方，ワッシャーを用いた場合にお いても，曲げモーメントによる高い圧縮応力がワッシ ヤーおよび板の穴周囲に作用するが，ワッシャーの強 度がリベット軸の強度よりも高いため，ワッシャーの 穴周囲は穴が拡大寸るようには塑性変形しない，その ため，穴周囲のき裂発生が防止されるものと考えられ 
る. その結果，継手の最大引張荷重は，板の穴周囲が 破壊する場合（ワッシャーを用いない場合）の引張荷 重を越えて，リベット軸がせん断破壊するまで増加す るものと考えられる. 以上のことから，ワッシャーを 用いる効果は，単せん断重亦継手の板の穴周囲に生じ る大きな圧縮応力による板の破壊を防止することにあ ると考えられる. 㮸って，曲げモーメントが作用しな い継手では，ワッシャ一を用いる効果は少ないと考え られる. そこでこれらのことを検討するため，曲げモ ーメントが作用しない複せん断リベット継手を作製し， ワッシャーを用いた場合と用いない場合の継手の最大 引張荷重について検討した.

図 14 は, ワッシャーを用いない場合とリベット頭部 の両方にワッシャーを用いた場合の複せん断継手の破 壊の样相,ならびに継手の最大引張荷重を示している. 先ず，図 14(A)に示寸複せん断継手は，いずれも中段 の板の穴周用か破壊している. 次に, 図 14(B)から, ワッシヤーを用いない場合とリベット頭部の両方にワ ッシャーを用いた場合の継手の最大引張荷重は，ほと んど変わらない，以上のことから，曲げモーメントが 作用しない複せん断継手では, ワッシャーを用いても 締結強度は増加しないことが和かった。この結果は理 論的考察の妥当性を裏付けているものと考えられる.

さらに，単せん断重亦継手の引張試験において，板 の穴周囲の変形に及ぼすワッシャーの影響について, より詳細に検討するため有限要素解析も行った. 継手 の引張試験の解析は, 有限要素コードMarc を使用して, A1070BD材のリベットとA1100P-0材の板を組合せた場 合のワッシャーを用いた場合と用いない場合について 行った. 図 15 は計算モデルを示し, 表 2 は計算条件を 示している．計算モデルは，実験で作製した継手の形 状とほぼ同じ形状とし，図に示す寸法・形状のリベッ トが板を締結しているものとした．なお，計算時間短 縮のため, 板幅の中心線で分割した $1 / 2$ モデルを用い， さらに図 3 に示寸継手の引張試験における板のチャッ ク部をモデル化せず板の全長を短くしている．解析方 法には，変形体と変形体の接触を考慮した三次元微小 変形弹塑性解析を用いた。本解析は，リベット頭部の 締付け力を作用させた状態での引張解析ができないた め, 継手の両端が引張られ，曲げモーメントが作用す ることにより生じる部材間の摩擦力のみを考慮した簡 便なモデルを用い；初期状態における全ての部材の内 部応力を 0 とし，継手の両端を $\mathrm{x}$ 軸と平行にそれぞれ 0. $1 \mathrm{~mm}$ まで少しずつ変位させることにより行った. 各 部材は計算時間短縮のため弾完全塑性体とし，摩擦条 件にはクーロン摩擦を適用した。

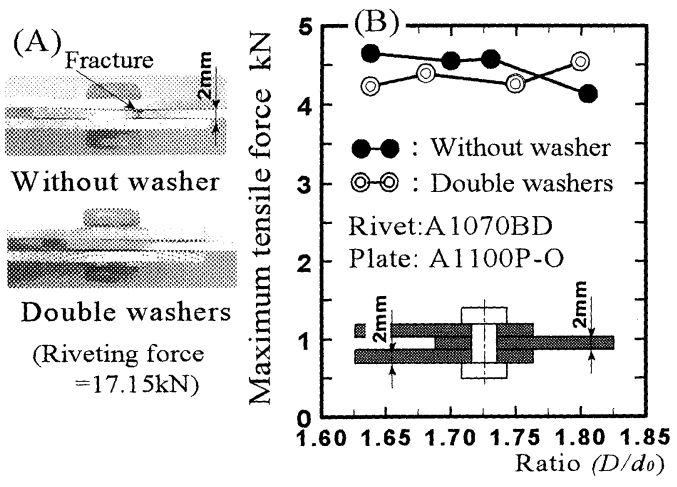

Fig.14 Fracture and maximum tensile force of double shear joint in case of using washers

図 16 は,継手の両端を $0.1 \mathrm{~mm}$ まで変位させた場合の 最大主応力の分布を示している. 先ず, 継手の変形後 の形状から，ワッシャーを用いた場合と用いない場合 の両方において，曲げモーメントの作用によりリベッ 卜軸が傾くとともに板と板の接合面に開きが生じる現 象が確認できる．最大主応力は，ワッシャーを用いた 場合と用いない場合の雨方において，大まかに，リ心゙ ット軸に押しつぶされる側の穴周辺は圧縮応力の分布, 引張られる側の穴周辺は引張応力の分布となっている. これは3·4の理論的考察におけるモデル図の図13 と対 応しており, $3 \cdot 4$ の理論的考察の妥当性を裏付けてい るものと考えられる．この結果から，ワッシャーを用 いた場合は，ワッシャーと板との接触部付近一帯が圧 縮応力の分布となっており，この圧縮応力が板の穴の 拡大を抑制する効果をもたらすものと考えられる。 そ こで㳄にワッシャーにより板の穴周囲の塑性変形を検 討した. 図 17 は, 板の穴内のリベット軸側面と接触し ている Nodel および Node11 における（相当）塑性ひ ずみと板の端面の変位との関係を表したものである.

Nodel およびNode11 は，図 15 中に示すように，共に 板の穴内にある $\mathrm{y}=0$ 面上の節点で, Nodel は板と板の 接合面上に亦る節点, Node11 は板穴の上側の縁にある 節点である.この図から，ワッシャーを用いた場合で は，板の穴緣の塑性ひずみがワッシャーを用いない場 合よりも小さくなることが和かる. 特に, ワッシャー と接している Nodel1 の塑性ひずタが小さく抑えられ ていることが確認できる，なお，有限要素解析による と，ワッシャーを用いない場合の塑性ひずみは，

Nodell 付近だけではなく Nodel 付近も大きい.これ は曲げモーメントが作用してリベット軸が傾くことに より板が開きだすと下面の穴緣が強く圧縮されるため と考えられる. 以上のことから，簡便なモデルの解析 


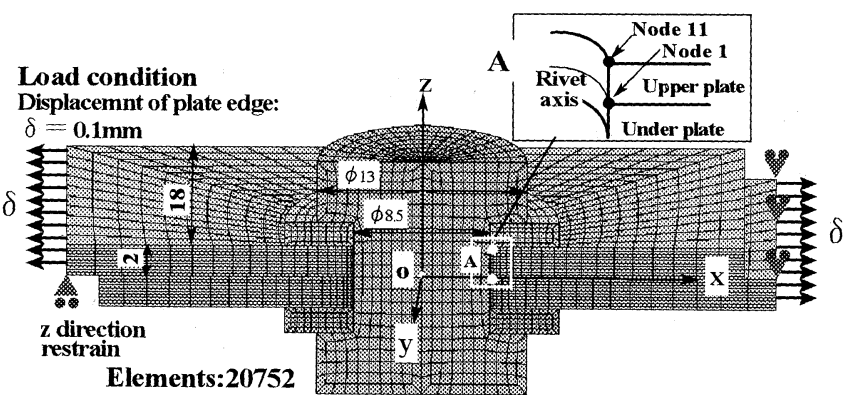

Fig. 15 FEM model for tensile test of joint

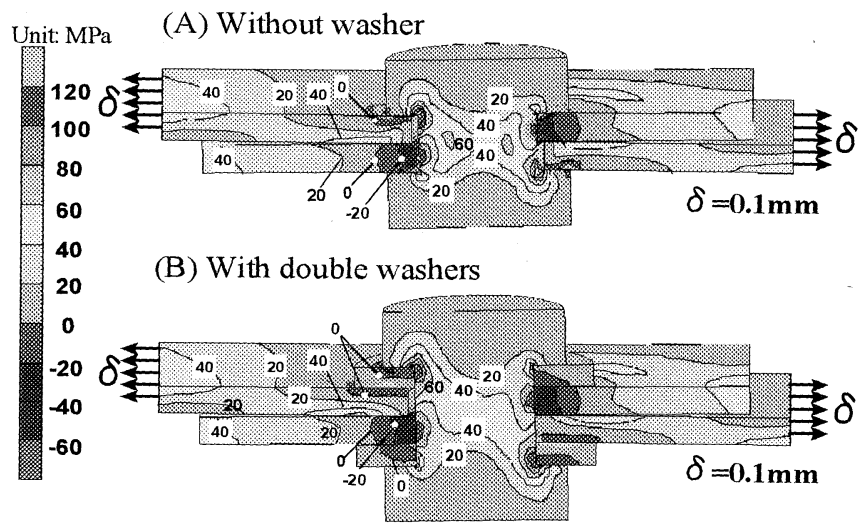

Fig. 16 Maximum principal stress distributions
Table 2 Computational conditions

\begin{tabular}{|l|l|}
\hline Method & 3-D small elastic-plastic analysis \\
\hline Materials & Elastic-perfectly-plastic(all materials) \\
\hline Yield stress & $\begin{array}{l}\text { Plates(62MPa), Rivet(90MPa), } \\
\text { Washers(150MPa) }\end{array}$ \\
\hline Young's modulus & $\begin{array}{l}\text { Plates and Rivet(70GPa), } \\
\text { Washers(100GPa) }\end{array}$ \\
\hline Poisson's ratio & 0.3 (all materials) \\
\hline $\begin{array}{l}\text { Friction } \\
\text { condition }\end{array}$ & $\begin{array}{l}\text { Coulomb friction, } \mu=0.3 \\
\text { (all between material and material) }\end{array}$ \\
\hline
\end{tabular}

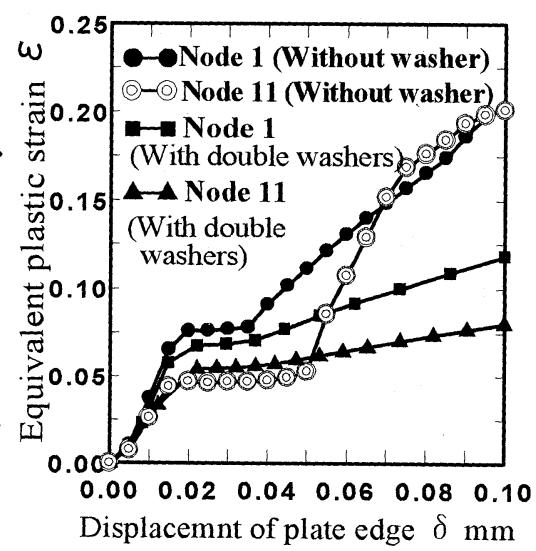

Fig. 17 Increase of equivalent plastic strain at Nodel and Node11

結果ではあるが，ワッシャーにより板の穴周囲の塑性 変形が小さく抑えられる効果があることを確認できた。

\section{4. 結言}

本研究では，板のひずみや反りなどの変形を小さく 抑えつつ高い締結強度を得ることを目的として，先ず リベット材と板材の硬度および変形抵抗の違いに着目 し，リベット材と板材の組合せを変えてリベット締結 を行い，継手の変形と強度について検討した，その結 果から, 次のような問題点があることを明らかにした。

(1) リベット材と板材の硬度および変形抵抗が同じ程 度の場合，およびリベット材の硬度が板材よりも 高く, 変形抵抗も相対的に大きい場合において, 過大なリベット軸の太りが生じやすく, 継手の変 形が大きくなりやすい．

(2)継手の変形を小さくするためには, リベット締め荷 重を小さくする必要があるが，リベット締め荷重 を小さくすると高い締結強度は得られない。

次に, これらのリベット材と板材の組合せにおいて 生じる問題点を改善するために，ワッシャーを用いて リベット締結する方法を提案し, その効果について寒 験および有限要素解析から検討した，その結果から，
以下のことを明らかにした。

（3）単せん断重吝継手の場合には,ワッシャーを用いて 板を締結することにより，過大なリベット軸の太 りを抑えるとともに，板の寸法変化と反りを小さ くすることができる，また，ワッシャーにより板 の穴周囲の破壊が抑制され継手の強度が増加寸る. なお，ワッシャーを用いて板を締結する場合は，ワ ッシャーが変形しないことが要件となる.

\section{文献}

(1) Kinoshita, H. et al., Mechanical Engineering Congress of the Japan Society of Mechanical Engineers, Vol. 6, No. 06-1 (2006), pp. 173-174.

(2) Kinoshita, H. et al., DISTORTION AND JOINT STRENGTH OF RIVETED PLATES, Proceedings of ASMP2006, (2006), p.112.

(3) Masuko, M., Machine Design, (1985), pp.71-92, Yokendo Co. Ltd.

(4) Watanabe, N., Bridge Engineering, (1974), pp.260-261, Asakura Publishing Co. Ltd.

(5) Simada, S., Design of steel structure (Rivet joint) http://www.nakanihon.co.jp/gijyutsu/Shimada/shimadato p.html

(6) Kawada, M., Machine Element Design, (1968), pp.59-60, Kyoritsu Shuppan Co. Ltd. 